\title{
BIOGAS INSTALLATIONS FOR HARVESTING ENERGY AND UTILIZATION OF NATURAL FERTILISERS 1
}

\author{
Kinga Borek ${ }^{\mathrm{a}^{*}}$, Wacław Romaniuk ${ }^{\mathrm{b}}$
}

${ }^{a}$ Institute of Technology and Life Sciences, Branch in Warsaw, Department of Technical Infrastructure Systems of Rural Areas, Poland, e-mail: k.borek@itp.edu.pl, ORCID 0000-0002-0171-7498

b Institute of Technology and Life Sciences, Branch in Warsaw, Department of Technical Infrastructure Systems of Rural Areas, Poland, e-mail: w.romaniuk@itp.edu.pl, ORCID 0000-0001-7776-9940

*Corresponding author: e-mail: k.borek@itp.edu.pl

\begin{tabular}{ll}
\hline ARTICLE INFO & ABSTRACT \\
\cline { 2 - 2 } $\begin{array}{l}\text { Article history: } \\
\text { Received: December 2019 } \\
\text { Received in the revised form: }\end{array}$ & $\begin{array}{l}\text { Development of innovative technological solutions in animal produc- } \\
\text { tion should be associated with reduction of greenhouse gases, ammo- } \\
\text { January 2020 }\end{array}$ \\
$\begin{array}{l}\text { nia emission, and with rational disposal of natural fertilizers. The } \\
\text { presented solutions and concepts of biogas acquisition and its disposal }\end{array}$ \\
$\begin{array}{l}\text { Key words: } \\
\text { natural fertiliser, } \\
\text { methane fermentation, } \\
\text { biogas, }\end{array}$ technological process before the science. The main aim of the present- \\
environment & $\begin{array}{l}\text { ed solutions for the use of methane fermentation of a natural fertiliser } \\
\text { in agricultural conditions is their utilization and energy acquisition, in }\end{array}$ \\
particular for households and farms. When considering the issue of \\
methane fermentation, one should include all favourable fertilization, \\
energy aspects and firstly, the ecological ones. During the methane \\
fermentation, substrates are stabilized due to removal of a large \\
amount of carbon. The only elements that are removed from the \\
system are evolving gases: $\mathrm{CH}_{4}, \mathrm{CO}_{2}$ and $\mathrm{H}_{2} \mathrm{~S}$. During the discussed \\
process, the entire nitrogen is preserved in the organic or ammonia \\
form.
\end{tabular}

\section{Introduction}

The simplest biogas installation comprises the biomass preparation and feed system, a digester, storage tank for fermented substrate, biogas tank and depending on the electrical energy or thermal energy production, generation, or cogeneration set.

\footnotetext{
${ }^{1}$ The publication of this study is supported through the project entitled: "Interdisciplinary research on improving energy efficiency and increasing the share of renewable energy sources in the energy balance of Polish agriculture", agreement no BIOSTRATEG1/269056/5/NCBR/2015 11.08.2015 r. financed by the National Center for Research and Development as part of the program BIOSTRATEG.
} 
Kinga Borek, Wacław Romaniuk

\section{Stages and effects of methane fermentation}

Methane fermentation is a biochemical process with four basic stages: hydrolysis, acid phase, acetogenesis, methanogenesis. Each of these stages is carried out by relevant bacteria.

Methane fermentation in relation to the temperature may be divided into three groups:

- psychrophilic fermentation $4-27^{\circ} \mathrm{C}$ - fermentation which takes place slowly and the amount of the biogas produced in this process is small;

- mesophilic fermentation $27-44^{\circ} \mathrm{C}$ - in this temperature, majority of fermentation chambers works, the amount of the obtained biogas is higher than in case of psychrophilic fermentation;

- thermophilic fermentation $48-70^{\circ} \mathrm{C}$ - temperature in which the highest amount of biogas is obtained.

The mixing treatment is also a crucial factor which influences the fermentation. Mixing causes uniformity of the entire consistence and maintains the same temperature of substrates (Mano Esteves, et al., 2019, Kuźnia, et al., 2018, Alburquerque, et al., 2012, Węglarzy, Podkówka, 2010).

Post-fermentation substance, except for biogas, is a product that is formed in biogas plants. As early as at the stage of planning of a biogas plant, one should remember about the formation of the post-fermentation residue and its disposal. Pursuant to the act on waste as of 14 December 2012 (Journal of Laws, 2013 item 21 consolidated text), waste mean each substance or object, which the owner disposes, plans to dispose or to the disposal of which he/she is obliged. Pursuant to article 18 paragraph 1 of the said act, everyone who undertakes actions that cause or would cause waste formation, should plan, design and lead such actions with the use of such production methods or service forms, raw materials and materials to, first of all, prevent waste formation or limit the amount of waste and their negative impact on human life, health and environment, including, production, during or after their use (Maldaner, et al., 2018).

Pursuant to the polish act on waste, the waste holder who deals with its recycling is obliged to maintain a register of the amount and quality of the recycled waste. This register must include, inter alia, disposal methods and data on its origin and destination of particular waste according to the Resolution of the Minister of Environment as of 9 September 2014 on the catalogue of waste (Journal of Laws, 2014, item 1923).

Post-fermentation residue is a result of the anaerobic digestion process, the main objective of which is to obtain the product in the form of methane mixed with other gases which after cleaning should be used for production of electric energy and (or) thermal one. If only plant products and/or animal ones were used for biogas process, then the digestate residue used on the own soil for fertilisation is not a waste (in the meaning of provisions on waste). Such residues may also be introduced to turnover as an organic fertiliser or a substance that improves the soil properties if they meet the requirements of the provisions of the act on fertilisers and fertilisation.

The digestate residue constitutes a product that requires further action with regard to disposal. A type of the post-fermentation residue depends on the substrate which was used for the process of methane fermentation (Zemo, et al., 2019, Mano Esteves, et al., 2019).

The most often used organic raw materials from agricultural production are (KOWR, 2018): 
Biogas installations...

- manure, liquid manure, droppings (manure of farm animals),

- maize silage,

- grass and wheat silage

- straw,

- plant mass waste,

- energy crops,

- organic substances of plant production.

\section{Elements of agricultural biogas plants}

The fundamental units of biogas installation which decide on the effectiveness of energy production are:

- a digester (bioreactor),

- initial tank for preparation of substrate,

- co-generation aggregate,

- gas tank,

- digestate mass tank.

A digestate mass tank should have a cylindrical shape and a height of the digester. The storage period of the digestate mass in the tank should be 6 months and it should include a period, in which the ground is frozen (a winter season), when a fertiliser cannot perceive a soil there is a risk that it will be washed away and surface water may get contaminated (Wardal, et al., 2015, Kowalczyk-Juśko, 2013, Myczko, et al., 2011).

Table 1.

Characteristics of input data depending on the need for aggregate power

\begin{tabular}{lccccc}
\hline System type & $\begin{array}{c}\text { Power } \\
\text { of aggregate }\end{array}$ & Digester & $\begin{array}{c}\text { Manure/ } \\
\text { liquid manure }\end{array}$ & $\begin{array}{c}\text { Surface area of } \\
\text { energy crops }\end{array}$ & $\begin{array}{c}\text { The surface } \\
\text { area of a silo }\end{array}$ \\
\hline $\mathrm{G}$ & $20 \mathrm{~kW}$ & $400 \mathrm{~m}^{3}$ & $17 \mathrm{~m}^{3}$ per day & 0 ha & $0 \mathrm{~m}^{3}$ \\
\hline $\mathrm{S}$ & $75 \mathrm{~kW}$ & $800 \mathrm{~m}^{3}$ & $\begin{array}{c}1800 \mathrm{~m}^{3} \text { of liquid manure } \\
1150 \mathrm{t} \text { of manure }\end{array}$ & $20 \mathrm{ha}$ & $1100 \mathrm{~m}^{3}$ \\
\hline $\mathrm{L}$ & $110 \mathrm{~kW}$ & $900 \mathrm{~m}^{3}$ & $\begin{array}{c}1800 \mathrm{~m}^{3} \text { of liquid manure } \\
1150 \mathrm{t} \text { of manure }\end{array}$ & $30 \mathrm{ha}$ & $1700 \mathrm{~m}^{3}$ \\
\hline $\mathrm{XL}$ & $150 \mathrm{~kW}$ & $1100 \mathrm{~m}^{3}$ & $\begin{array}{c}1800 \mathrm{~m}^{3} \text { of liquid manure } \\
1150 \mathrm{t} \text { of manure }\end{array}$ & $50 \mathrm{ha}$ & $2700 \mathrm{~m}^{3}$ \\
\hline $\mathrm{XXL}$ & $180 \mathrm{~kW}$ & $1200 \mathrm{~m}^{3}$ & $\begin{array}{c}1800 \mathrm{~m}^{3} \text { of liquid manure } \\
1150 \mathrm{t} \text { of manure }\end{array}$ & $60 \mathrm{ha}$ & $3300 \mathrm{~m}^{3}$ \\
\hline
\end{tabular}

Source: AgriKomp France (2011)

In the continuous (wet) digestion, single-stage installations which work according to the flow method are the most often used. In two-stage installations, an initial digestate which opens the process is connected to the proper digester in two-stage installations. The most favourable conditions for the first of two stages of the decomposition process (hydrolysis and acid phase) are set in the chamber. The substrate is provided to the main chamber from 
the initial chamber. There, another two stages of methane fermentation took place - acid phase and methanogenesis. The digestate mass is stored in closed digesters for fermentation with biogas harvesting or in open tanks for digestate mass and as a rule as a liquid fertiliser, they are applied to agricultural fields or may undergo separation (Owczuk et al., 2013).

Selection of the size of the digester and the size and type of substrate indispensable to determine the designed power of the aggregate is presented in table 1 and in table 2 presents a livestock and the area of arable land.

Table 2.

A livestock unit and indispensable area of arable land (ha) for obtaining a plant substrate referred to the installation type from table 1

\begin{tabular}{lcc}
\hline System type & $\begin{array}{c}\text { Livestock unit } \\
(\text { LU) }\end{array}$ & $\begin{array}{c}\text { Area of arable land } \\
\text { (ha) })\end{array}$ \\
\hline $\mathrm{G}$ & 340 & $340-510$ \\
\hline $\mathrm{S}$ & 200 & $220-330$ \\
\hline $\mathrm{M}$ & 200 & $230-330$ \\
\hline $\mathrm{L}$ & 200 & $250-350$ \\
\hline $\mathrm{XL}$ & 200 & $260-360$ \\
\hline $\mathrm{XXL}$ & 200 & $290-390$ \\
\hline & & Source: AgriKomp France (2011)
\end{tabular}

Particular values of biogas installations, starting with the " $G$ " installation with the power of the co-generation aggregate amounting to $20 \mathrm{~kW}$ to the power of $250 \mathrm{~kW}$-"XXL" the sizes of digesters, amounts of needed liquid manure, surface area of crops, cubic capacity of a silo for storing silage are assigned. The provided parameters of particular technological knots (modules) are determined approximately, however, they enable making assumptions to specific projects.

Realisation of the investment of biogas plant construction requires actions set forth in the applicable provisions. A building permit and documentation are necessary for the initial stage of realisation of the biogas plant project. As a part of the assessment, making a report on the influence of the undertaking on the environment - in case of the system exceeding $500 \mathrm{~kW}$ of power, may be required. Making a report may be needed if the biogas plant system serves for neutralization of waste from agriculture and food processing. Furthermore, obtaining a permit for construction of biogas installations requires a construction project pursuant to the requirements included in the Construction Law.

\section{The use of biogas installations in practice - an exemplary biogas plant with a digester with the cubic capacity of $100-500 \mathrm{~m}^{3}$}

A conceptual scheme of the test stand was presented in figure 1. Liquid manure from the livestock building gravitationally flows from the initial chamber. In this tank, liquid manure is mixed with an impeller pump and then transported with a pipe to the fermentation chamber.

The digester is supplied once a day with a daily production of liquid manure. Equipping the chamber with a flow pipeline ensures evacuation of the same amount of post- 
Biogas installations...

fermentation liquid manure which was supplied to the digestate at the storage tank of the compost chamber. It is planned to carry out a three-times repeated mixing of the content of the digestate during a day with a mixing hydraulic system. Each time, the mixing time will be ca. 10 minutes.

A supplementation of the above concept is a scheme of the digestate system with elements of devices for the supply of the substrate from natural fertilisers and plant biomass. The substrate subjected to methane fermentation is periodically mixed in the presented system with a blade mixer.

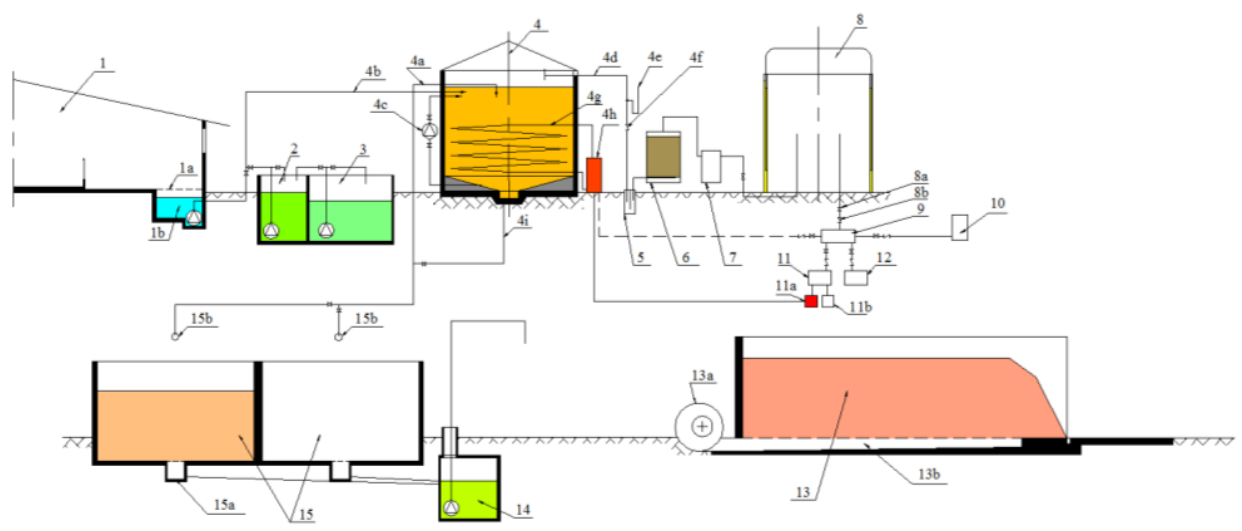

Figure 1. Technology of biogas and biofertilizer production with digester of 100-500 $\mathrm{m}^{2}$ : 1 - livestock building; $1 a$ - grillage; $1 b$ - liquid manure channel (initial tank); 2 - preparatory tank for the batch to biogas plant; 3 - tank for plant substrate (e.g. corn silage); 4 -digester; $4 a$ - flow into biogas plant; $4 b$ - supplying pipeline; $4 c$-mixing pipeline; $4 d$-gas pipeline; $4 e$-fuse; $4 f$-flame trap; $4 g$-heater; $4 h$-heat exchanger from cogeneration unit or gas stove; $4 i$ - conduit for evacuation of sediment from bottom of chamber; 5 -dehydrator; 6-desulphurizator; 7 - gas meter; 8 - gas tank; $8 a$ - gas valve; 8b-flame trap; 9 -gas seperator; 10 -facula; 11-cogeneration unit; 11a-hot water; 11b-current; 12 - gas for own use or sale; 13 - compost disc covered with wood chips; 13 a -fan for aeration of compost; $13 b$ - airing channel for compost mass; 14 - tank for effluent with a pump for effluent for further application; 15 - chambers for post-fermentation mass and compost elements (acc. to figure 3); $15 a$-dehydrating channels; $15 b$-ending of conduit for the post-fermentation mass that supplies the compost chamber 


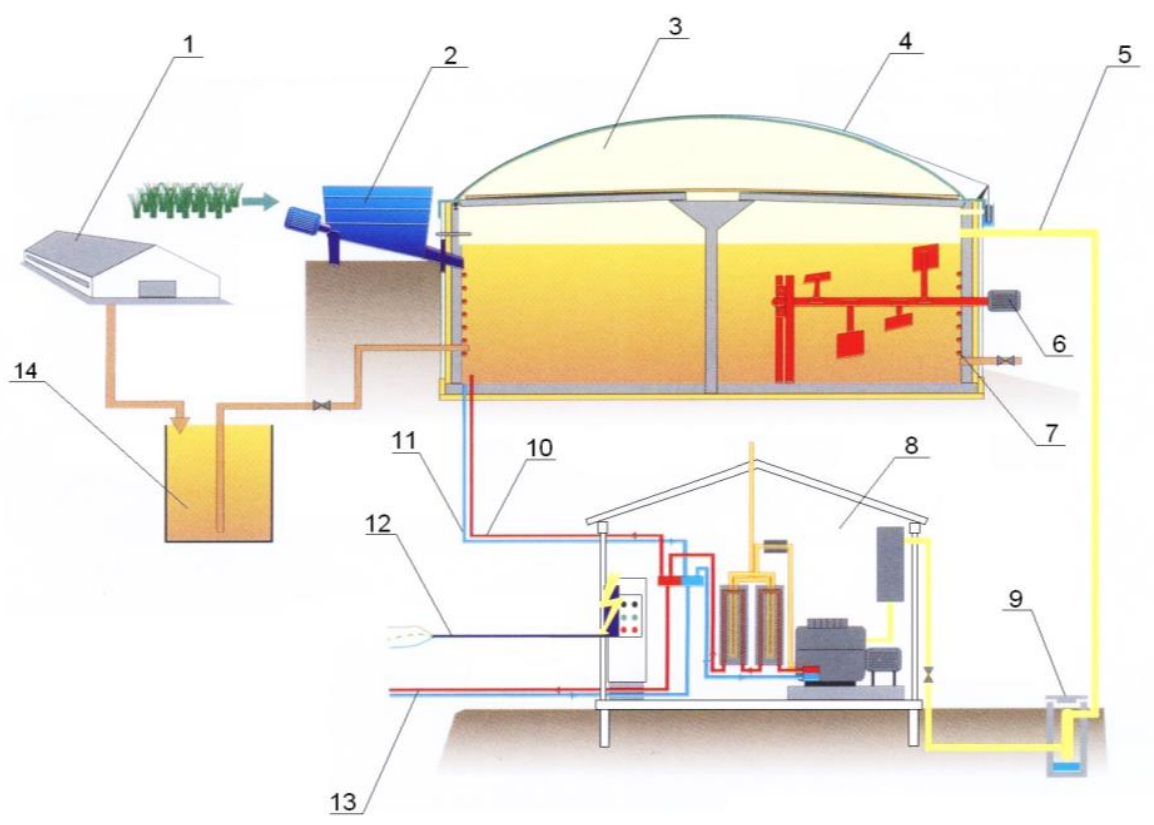

Figure 2. Scheme of fermentation chamber system with elements of devices for supply with substrates (liquid manure+ plant biomass): 1-cowshed; 2 - biomass dosing system; 3 -fermentation tank; 4 -biogas tank membrane; 5 -biogas conduit; 6 - mixer; 7 - heating system; 8 -machine room with aggregate; 9 -dehydrator; 10 -thermal energy supply conduit; 11 - cooled liquid/water evacuating conduit; 12 - electric energy evacuating conduit; 13 - thermal energy transport; 14 -initial tank

Source: AgriKomp France (2011)

The pump system is shown schematically in Figure 1. However, Figure 2 shows the system for mixing fermentation mass with a low-speed blade mixer with a hydraulically driven engine. The mixing system pump, e.g. type UM 200-125, sucks the slurry from the bottom of the chamber and pushes it to the top. A downpipe enables emptying of the fermentation chamber by evacuation of its content to the storage tank for fermented liquid manure. In the digester bigger than $500 \mathrm{~m}^{3}$, there is a blade mixer with slow rotations with a moto-reducer installed on the outside concrete shield of the digester. On the outside of the shield of the digester, conduits for the $\mathrm{CO}$ system made with polyurethane are mounted.

For gas purification two desulphurizators that operate in series, and a dehydrator were used. The desulphurisation process will consist in letting gas through the desulphurisation mass placed on the shelves of desulphurisators. The main constituent of the desulphurisation mass is bog iron. A gas meter enables control of gas production. Gas is stored in the bell tank. Gas pressure required for correct operation of gas devices is $150-200 \mathrm{~mm} \mathrm{H}_{2} \mathrm{O}$. Gas from the chamber is moved to the water heater the operation of which is automatized. 
Biogas installations...

The water heater is adjusted to the use of two energy sources: electric, turned on with a start-off, and in case of the biogas plant failure, and biogas.

Hot water for heating the digestate mass is led from the generator with pipelines to the heater of the chamber. Its task is to lead the temperature of the liquid manure to ca. $36^{\circ} \mathrm{C}$ and maintain it in the fermentation process. A temperature regulator (a thermostat) ensures a permanent temperature of liquid manure. The remaining part of gas will be used in the gas systems (devices) in a farm. A fresh liquid manure is provided to the digester in two portions each $2.5 \mathrm{~m}^{3}$ each (4\% of the digester cubic capacity). The first portion is provided at 7 and the second one at $3 \mathrm{p} . \mathrm{m}$. The provided liquid manure has a temperature of ca. $20^{\circ} \mathrm{C}$. In the digestate the temperature is ca. $36^{\circ} \mathrm{C}$. After adding one portion in the amount of $2.5 \mathrm{~m}^{3}$ and after homogenization with a mixing pump, the temperature in the digester lowers usually by $0.5^{\circ} \mathrm{C}$. In such conditions of operation, the system even in unfavourable temperature of the surrounding, produces daily $70 \mathrm{~m}^{3}$ net of biogas with the content of elements provided in table 3 .

Results of research on liquid manure with regard to reduction of contamination before and after methane fermentation were presented in table 4.

Table 3 .

Average content of biogas elements (\%)

\begin{tabular}{lcc}
\hline Biogas elements & June & October \\
\hline $\mathrm{CH}_{4}$ & 56.2 & 59.95 \\
$\mathrm{CO}_{2}$ & 40.1 & 35.79 \\
$\mathrm{H}_{2} \mathrm{~S}$ & 0.5 & 0.55 \\
$\mathrm{CO}$ & 0.3 & 0.40 \\
$\mathrm{~N}_{2}$ & 2.9 & 3.31 \\
\hline
\end{tabular}

Source: author's own research

Table 4.

Characteristics of liquid manure before and after methane fermentation

\begin{tabular}{lccc}
\hline Symbols & Unit & $\begin{array}{c}\text { Before } \\
\text { fermentation }\end{array}$ & $\begin{array}{c}\text { Post } \\
\text { fermentation }\end{array}$ \\
\hline $\mathrm{COD}\left(\mathrm{K}_{2} \mathrm{Cr}_{2} \mathrm{O}_{7}\right)$ & $\mathrm{mg} \cdot \mathrm{dm}^{-3}$ & 810.0 & 380.0 \\
$\mathrm{BOD}_{5}$ & $\mathrm{mg} \cdot \mathrm{dm}^{-3}$ & 476.0 & 290.0 \\
General suspension & $\mathrm{mg} \cdot \mathrm{dm}^{-3}$ & 55.5 & 44.0 \\
Mineral suspension & $\mathrm{mg} \cdot \mathrm{dm}^{-3}$ & 4.4 & 3.6 \\
Dry residue & $\mathrm{mg} \cdot \mathrm{dm}^{-3}$ & 74.0 & 59.0 \\
Residue after roasting & $\mathrm{mg} \cdot \mathrm{dm}^{-3}$ & 15.4 & 15.0 \\
Phosphates & $\mathrm{mg} \cdot \mathrm{dm}^{-3}$ & 0.032 & 0.022 \\
General phosphorus & $\mathrm{mg} \cdot \mathrm{dm}^{-3}$ & 0.011 & 0.007 \\
Ammonia nitrogen & $\mathrm{mg} \cdot \mathrm{dm}^{-3}$ & 0.208 & 0.126 \\
Nitrate nitrogen & $\mathrm{mg} \cdot \mathrm{dm}^{-3}$ & 0.078 & 0.050 \\
\hline
\end{tabular}

Source: author's own research 
Factors that favour correct fermentation in biogas plants are as follows:

- range of temperatures $35-38^{\circ} \mathrm{C}$ (but it is recommended to maintain constant temperature);

- dry mass content at least 5\%;

- hydraulic or mechanical mixing (preventing delamination of liquid manure into fractions and activating bacteria work);

- reaction $\mathrm{pH}=6,5-7,5$;

- proportion of $\mathrm{C}$ to $\mathrm{N}_{\max }=100$ to 3 . Methane fermentation of agricultural waste, especially of liquid manure, enables the following statement:

1. One of the fermentation products is flammable biogas with dominance of methane in the amount of $1.0 \mathrm{~m}^{3}$ (on average) from $1 \mathrm{~m}^{3}$ of the chamber with the calorific value of ca. $23 \mathrm{MJ} \cdot \mathrm{m}^{-3}$.

2. Another product of anaerobic process is fermented manure that has better fertilization and sorption properties than the raw one, because:

- during the fermentation, no loss of precious nitrogen is observed and only reduction to ammonia nitrogen, which is more assimilated by plants;

- $\mathrm{pH}$ increases from 7 to 8 ;

- it reduces the content of organic substances by $30-50 \%$ which causes reduction of the carbon to nitrogen proportion $(\mathrm{C}: \mathrm{N})$; it is very favourable if the fermented liquid manure is poured out onto the fields where post-harvest or post -pasture remains occur;

- phosphorus and potassium occur also in the more easily assimilated form for plants;

- weed seeds lose their germination capacity;

- fermented liquid manure has less unpleasant smell and more favourable consistency, it is better dehydrated.

3. fermented liquid manure reduces a sanitary threat for adjusting fields and residential areas since,

- the number of pathogenic bacteria is reduced to the minimum;

- burdening of soil, water, and plants with hazardous bodies which in the fermentation process are decomposed into simple compounds used in the sorption process of soil, is prevented;

- reduction of the cubic capacity of liquid manure, which facilitates its disposal is reported;

- basic contaminations such as: biochemical oxygen demand within 5 days (BOD5) are reduced by $60-90 \%$ and chemical oxygen demand (COD) by $50-60 \%$.

The second stage in the process of disposal of the post-fermentation substrate in order to carry out a more effective use, is a production of compost, the principle of which was presented in figure 3 . 
Biogas installations...

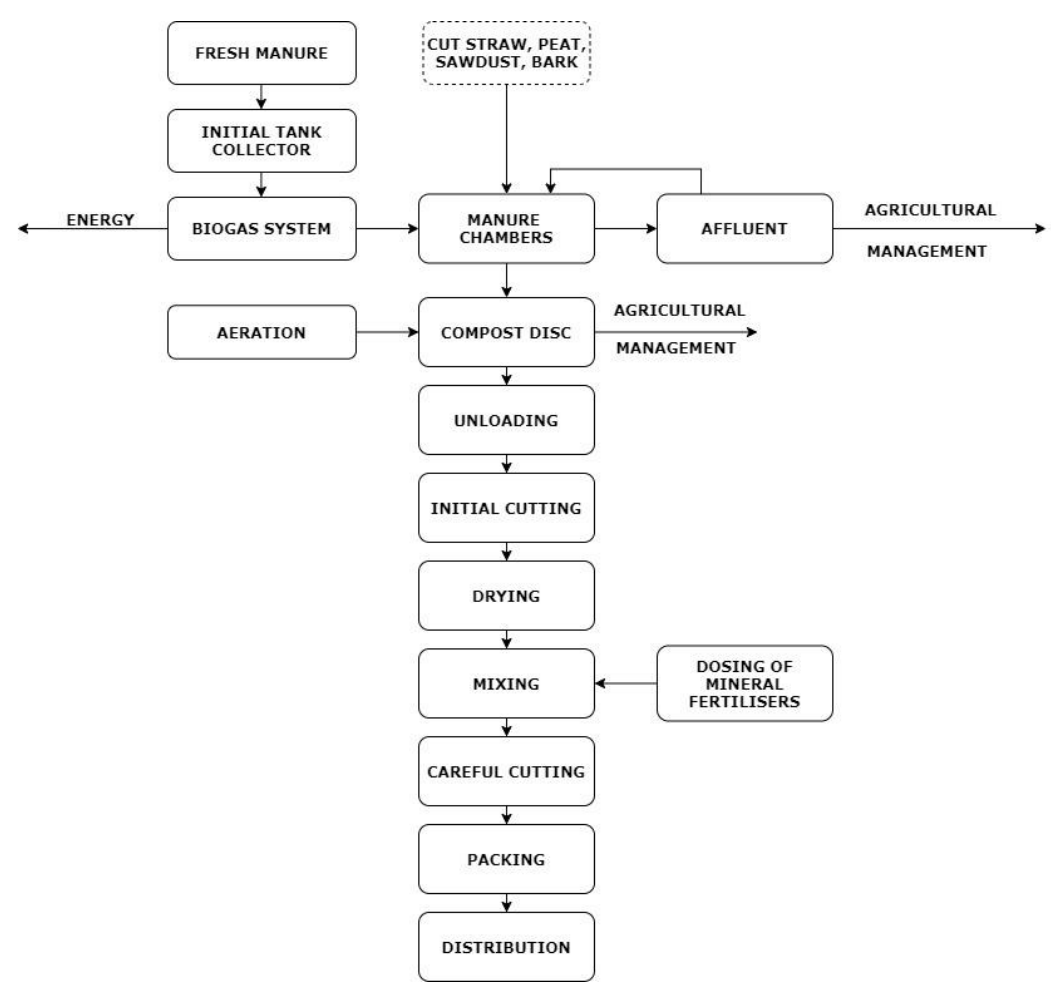

Figure 3. Schematic representation of processing of liquid manure and biogas harvesting and disposal of post-fermentation mass in a farm

Source: author's own study

\section{Exploitation tests results of a system in Studzionka (referring to the concept according to figure 1)}

Test results on the system in Studzionka were presented below. The test results enabled to carry out an economic and energy assessment and enabled orientation of further development works.

Characteristics of the process:

- mesophilic fermentation $\sim 37^{\circ} \mathrm{C}$;

- provision of raw material (substrate) $3 \mathrm{x}$ ca. $1 \mathrm{~m}^{3}$ daily;

- substrates: liquid manure from cattle production, dropping, maize silage;

- co-generation system with the electric power of $30 \mathrm{~kW}$ and thermal $40 \mathrm{MW}$;

- post-fermentation mass used as agricultural fertiliser;

- amount of energy produced from $1 \mathrm{~m}^{3}$ of gas to $2 \mathrm{kWh}$;

- content of $\mathrm{H}_{2} \mathrm{~S} 600-700 \mathrm{ppm}$;

- content of $\mathrm{NH}_{4} 55 \div 60 \%$;

- calorific value of biogas $20 \div 23 \mathrm{MJ} \cdot \mathrm{m}^{-3}$. 


\section{Basic units of the system}

The biogas plant in Studzionka comprises the following basic units:

- digester (bioreactor 1);

- digester (bioreactor 2);

- system for transport and storage of liquid manure;

- system for transport and storage of droppings;

- system for transport and storage of biogas;

- heating system;

- electrical system;

- electric energy production system.

Liquid manure produced by pigs is collected in channels under the slit floor and in the tank adjusting to a piggery, and from there it is provided to the digester three times daily. Fermentation in digesters takes place in a constant temperature of $35^{\circ} \mathrm{C}$. Liquid manure in the digester with the cubic capacity of $60 \mathrm{~m}^{3}$ is uniformed (mixed) with a mechanical mixer three times daily. The same amount of liquid manure which is added to the bioreactor 1 flows out automatically and is provided to the bioreactor 2 to which droppings from a laying house are added (Fig. 4). Periodically, maize silage or fragmented green mass in the amount of $300 \mathrm{~kg}$ was provided to the bioreactor. As a result of this operation, metres registered an increased biogas production by ca. $15 \%$. Fermented liquid manure from bioreactor 2 is collected in the digestate mass tank with a volume $75 \mathrm{~m}^{3}$. Condensate from steam included in biogas flows down to dehydrators. Produced biogas is stored in an elastic tank with capacity of $90 \mathrm{~m}^{3}$ and serves for supply of the generator with the power of $30 \mathrm{kWe}$ which processes biogas into electric energy. In the period of registration of measurements i.e. in May and September before starting of the generator (diesel engine) the content of hydrogen sulphide in biogas was investigated. According to the record, these values were within 600 to $700 \mathrm{ppm}$. These values are within the upper, safe limit of the aggregate engine operation. The produced energy designed for operation of a farm. Results from the research are presented in table 5 and 6.

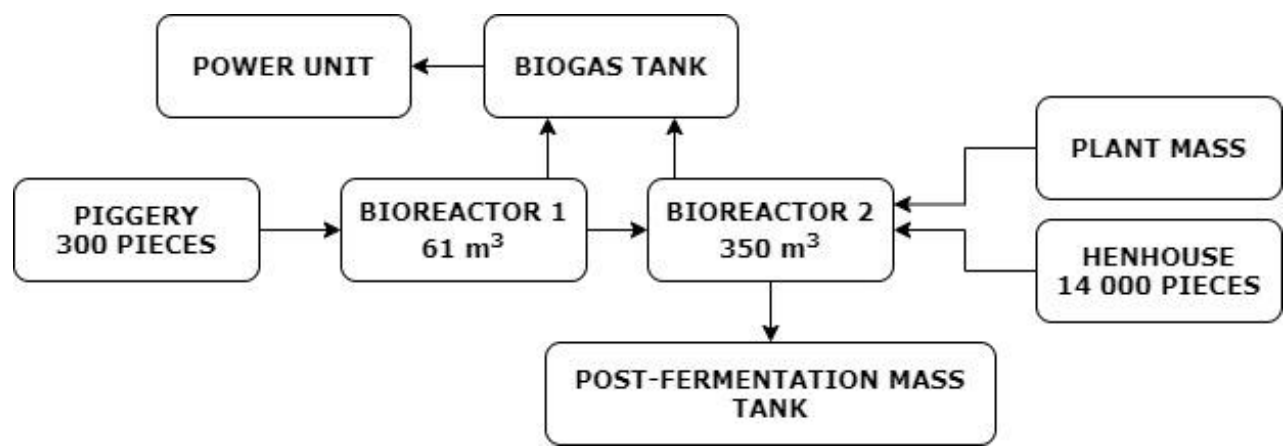

Figure 4. Schematic representation of the biogas installation in Studzionka 
Biogas installations...

Table 5.

Chemical composition of biogas and its energy value in Studzionka

\begin{tabular}{lccccccc}
\hline \multirow{2}{*}{$\begin{array}{l}\text { Intensity } \\
\text { of biogas production }\end{array}$} & \multicolumn{4}{c}{ Chemical composition (\%) } & \multicolumn{2}{c}{$\begin{array}{c}\text { Heat of } \\
\text { combustion } \\
\left(\mathrm{MJ}^{-3}\right)\end{array}$} & $\begin{array}{c}\text { Calorific } \\
\text { value } \\
\left(\mathrm{MJ}^{-3} \mathrm{~m}^{-3}\right)\end{array}$ \\
\cline { 2 - 8 } & $\mathrm{CH}_{4}$ & $\mathrm{CO}_{2}$ & $\mathrm{~N}_{2}$ & $\mathrm{O}_{2}$ & Other & 22.6 & 22.6 \\
$11.05 \div 31.05$. & 58.11 & 34.39 & 2.63 & 0.72 & 0.04 & 25.1 & 21.0 \\
$05.09 \div 25.09$. & 62.22 & 38.59 & 2.45 & 0.80 & 0.05 & 23.1 & Source: author's own research
\end{tabular}

Table 6.

Average values of indices for raw and fermented liquid manure obtained on the pig farm in Studzionka

\begin{tabular}{|c|c|c|c|c|}
\hline \multirow{2}{*}{ Parameters } & \multirow{2}{*}{ Unit } & \multicolumn{2}{|c|}{ Average data for manure } & \multirow{2}{*}{$\begin{array}{l}\text { Reduction } \\
(\%)\end{array}$} \\
\hline & & raw & fermented & \\
\hline $\mathrm{CHZT}$ & $\mathrm{g} \mathrm{O}_{2} \cdot 1^{-1}$ & 25.0 & 6.3 & 74.0 \\
\hline $\mathrm{BZT}_{5}$ & $\mathrm{~g} \mathrm{O}_{2} \cdot 1^{-1}$ & 16.3 & 1.2 & 92.5 \\
\hline Dry residue & $\mathrm{g} \mathrm{O}_{2} \cdot 1^{-1}$ & 17.9 & 7.5 & 41.7 \\
\hline $\begin{array}{l}\text { Oxygen } \\
\text { consumption }\end{array}$ & $\mathrm{g} \mathrm{O}_{2} \cdot 1^{-1}$ & 3.9 & 2.7 & 31.0 \\
\hline Suspension & $\mathrm{g} \mathrm{O}_{2} \cdot 1^{-1}$ & 9.9 & 4.3 & 56.2 \\
\hline
\end{tabular}

Realisation of the agricultural biogas plant construction project should include:

- availability of substrates,

- availability of water source,

- availability of transmission grids for receipt of generated electric and thermal energy,

- favourable access for vehicles that bring substrates and receive post-process material for agricultural purposes,

- selection of the biogas plant model (resulting from the composition of substrates and own demand for energy for maintenance of the fermentation process),

- maintenance of the distance to avoid the smell nuisance which may constitute a discomfort for local citizens,

- a legal evaluation including the environmental law, energy law, conditions for connecting to energy grids and energy sale, construction law, etc.,

- size of the biogas plant production results from the farm performance,

- the set of results obtained during investigation of the biogas plant in Studzionka including the set parameters, were presented in table 7. 
Kinga Borek, Wacław Romaniuk

Table 7.

The set of results at the assumed parameters of investigation of a biogas plant in Studzion$\mathrm{ka}$ - data obtained from the investor

\begin{tabular}{lcc}
\hline Parameters & Unit & Value \\
\hline $\begin{array}{l}\text { The total cubic capacity of fer- } \\
\text { mentation chamber of the biogas } \\
\text { plant }\end{array}$ & $\mathrm{m}^{3}$ & 410 \\
$\begin{array}{l}\text { Investment cost of the entire } \\
\text { installation (estimation) }\end{array}$ & $\mathrm{PLN}$ & 450,000 \\
$\begin{array}{l}\text { The amount of the produced } \\
\text { biogas within one year }\end{array}$ & $\mathrm{m}^{3}$ & 112,000 \\
$\begin{array}{l}\text { Calorific value of biogas } \\
\begin{array}{l}\text { The amount of produced electric } \\
\text { energy }\end{array}\end{array}$ & $\mathrm{MJ} \cdot \mathrm{m}^{-3}$ & 20.75 \\
$\begin{array}{l}\text { The amount of produced thermal } \\
\text { energy }\end{array}$ & $\mathrm{MW} \cdot \mathrm{year}^{-1}$ & 212 \\
$\begin{array}{l}\text { Possible yield from the sale of } \\
\text { the produced electric energy } \\
\begin{array}{l}\text { Market price of green certificates } \\
\text { of origin }\end{array}\end{array}$ & $\mathrm{MW} \cdot \mathrm{year}^{-1}$ & 246 \\
$\begin{array}{l}\text { Annual use of raw material } \\
\text { (liquid manure }+ \text { droppings) for } \\
\text { biogas production }\end{array}$ & $\mathrm{PLN} \cdot \mathrm{year}^{-1}$ & 100,622 \\
\hline
\end{tabular}

Source: author's own study

\section{Conclusion}

Production and use of farm energy are a chance for diversification and increase of agricultural income an energy safety of rural areas and improvement of environmental production on agricultural areas.

Biogas harvesting from natural fertilisers and other raw material of agricultural origin including organic waste as a result of methane fermentation gives a possibility of obtaining:

- Post-fermentation residue which is less burdensome for natural environment than natural fertiliser due to lower indices e.g. BOD5 (by ca. 90\%) and COD (by 50-60\%).

- Fermented mass, which does not constitute a sanitary threat for adjusting fields and residential areas with its chemical composition and physical properties since it reduces to the minimum the number of pathogens and pathogenic germs.

It also enables to:

- Reduce the risk of contamination of ground waters and surface water, with mainly nitrogen and phosphorus compounds and germs which occur in animal excrement (reduction of eutrophication of water).

- Destruction of seeds of weed which has a significant impact on chemical consumption of crop protection substances. 


\section{References}

AGRIKomp (2011). Quelle est l'installation la mieux adaptee a votre exploitation? (online). (Dostęp 15.10.2011). Dostępny w Internecie : http://agrikomp.de/fr/installations-de-biogaz-/trouvez-votreinstallation-.html

Alburquerque, J.A., Fuente, C., Ferrer-Costa, A., Carrasco, L., Cegarra, J., Abdad, M., Bernal, M.P. (2012). Assessment of the fertilizer potential of digestates from farm and agroindustrial residues. Biomass and Bioenergy, 40, 181-189.

Kowalczyk-Juśko, A. (2013). Biogazownie - szansą dla rolnictwa i środowiska. Fundacja na rzecz Rozwoju Polskiego Rolnictwa, 8-85.

KOWR (2018). Wykaz surowców zużytych do produkcji biogazu rolniczego w 2018 r. (online)(Dostęp: 19.12.2019 r). Dostępny w internecie: www.bip.kowr.gov.pl/uploads/pliki/ oze/biogaz/Surowce_w_2019_r..pdf

Kuźnia, M., Magiera, A., Jerzak, W., Pielichowska, K., Sikora, J. (2018). Biogas production from agricultural and muncipal waste. Energy and Fuels, 108, 1-8.

Maldaner, L., Wagner-Riddle, C., VanderZaag, A.C., Gordon, R., Duke C. (2018). Methane emissions from storage of digestate at a dairy manure biogas facility. Agricultural and Forest Meteorology, 258, 96-107.

Mano Esteves, E.M., Naranjo Herrera, A.M., Pecanha Esteves, V.P., do Rosario Vaz Morgado, C. (2019). Life cycle assessment of manure biogas production: A review. Journal of Cleaner Production, 219, 411-423.

Myczko, A., Myczko, R., Kołodziejczyk, T., Golimowska, R., Lenarczyk, J., Janas, Z., Kliber, A., Karłowski, J., Dolska, M. (2011). Budowa i eksploatacja biogazowni rolniczych - poradnik dla inwestorów zainteresowanych budowa biogazowni rolniczych. Instytut TechnologicznoPrzyrodniczy. Warszawa-Poznań. ISBN 978-83-62416-23-3.

Owczuk M., Wardzińska D., Zamojska-Jaroszewicz A., Matuszewska A. (2013). Wykorzystanie odpadów biodegradowalnych do produkcji biogazu jako alternatywnego źródła energii odnawialnej. Studia Ecologiae et Bioethicae UKSW, 11(3), 133-144.

Rozporządzenia Ministra Środowiska z dnia 9 września 2014 r. w sprawie katalogu odpadów (Dz.U. 2014 poz. 1923).

Ustawa o odpadach z dnia 14 grudnia 2012 r. (Dz.U. 2013 poz. 21 tekst jednolity).

Somers, M.H., Azman, S., Sigurnjak, I., Ghyselbrecht, K., Meers, E., Meesschaert, B., Appels, L. (2018). Effect of digestate disintegration on anaerobic digestion of organic waste. Bioresource Technology, 268, 568-576.

Wardal, W.J., Barwicki, J., Mazur, K., Majchrzak, M., Borek, K. (2015). Technical and economic aspects of biogas production from agricultural sources including Polish conditions. Agricultural Engineering, 19(2), 137-148.

Węglarzy, K., Podkówka, W. (2010). Agrobiogazownia. Opracowanie zbiorowe Grodziec Śląski. Zakład Doświadczalny Instytutu Zootechniki PIB; Balice k. Krakowa: Instytut Zootechniki- Państwowy Instytut Badawczy, 156.

Wróbel, M., Frączek, J., Jewiarz, M., Mudryk, K., Dziedzic, K. (2016). Impact of selected properties of raw material on quality features of granular fertilizers obtained from digestates and ash mixtures. Agricultural Engineering, 20(4), 207-217.

Zemo, K.H., Panduro, T.E., Termansen, M. (2019). Impact of biogas plants on rural residential property values and implications for local acceptance. Energy Policy, 129, 1121-1131. 
Kinga Borek, Wacław Romaniuk

\section{INSTALACJE BIOGAZOWE DO POZYSKANIA ENERGII ORAZ UTYLIZACJI NAWOZÓW NATURALNYCH}

Streszczenie. Rozwój innowacyjnych rozwiązań technologii w produkcji zwierzęcej powinien być skojarzony z ograniczeniem emisji gazów cieplarnianych, a także racjonalnym zagospodarowaniem nawozów naturalnych na cele nawozowe i energetyczne. Przedstawione rozwiązania i koncepcje pozyskania biogazu oraz jego zagospodarowania, a także zagospodarowania masy pofermentacyjnej stawiają przed nauką potrzebę doskonalenia procesu technologicznego. Głównym celem przedstawionych rozwiązań zastosowania fermentacji metanowej nawozu naturalnego w warunkach rolnictwa jest ich utylizacja, jak również pozyskanie energii, zwłaszcza dla gospodarstw rodzinnych i farmerskich. Rozpatrując zagadnienie fermentacji metanowej, należy uwzględnić wszystkie korzystne aspekty nawozowe, energetyczne, a przede wszystkim ekologiczne. Podczas fermentacji metanowej substraty podlegają stabilizacji w wyniku usunięcia dużej ilości węgla. Jedynymi usuwanymi z systemu składnikami są wydzielające się gazy: $\mathrm{CH}_{4}, \mathrm{CO}_{2} \mathrm{i} \mathrm{H}_{2} \mathrm{~S}$. W trakcie omawianego procesu cały azot konserwowany jest $\mathrm{w}$ formie organicznej lub amoniakalnej.

Słowa kluczowe: nawóz naturalny, fermentacja metanowa, biogaz, środowisko 